\title{
Internalisasi Karakter Qurani dengan Tartil Al-Qur'an
}

\author{
Agus Nur Qowim \\ Fakultas Tarbiyah Institut PTIQ Jakarta, Indonesia \\ agusqowim@gmail.com
}

\begin{abstract}
Abstrak:
Ilmu Tajwid harus dikuasai oleh setiap individu muslim dalam rangka mencapai hasil yang maksimal terkait ibadah membaca Kitab Suci al-Qur'an. Membaca al-Qur'an apabila merujuk kepada perintah Allah harus dilakukan dengan tartil yang maksimal, yakni mengetahui dan mematuhi setiap rambu-rambu yang ada. Pahala yang dijanjikan Allah berdasarkan sabda Rasulullah adalah barangsiapa yang membaca satu huruf baginya akan diganjar satu kebaikan yang akan dilipatgandakan juga 10 kali lipat. Kemukjizatan al-Qur'an tidak hanya sampai di situ. Apabila direnungkan lebih dalam, ilmu tajwid mengandung falsafah yang dalam, tidak hanya mendapatkan pahala dari Allah, namun pemahaman yang mendalam terhadap falsafahnya akan menghasilkan sebuah pemikiran tentang internalisasi, yakni panduan pembentukan karakter, atau akhlak yang sesuai dengan tuntunan al-Qur'an.
\end{abstract}

Kata Kunci: Ilmu Tajwid, Tartil, Internalisasi, Karakter Qur’ani

\begin{abstract}
:
Tajweed knowledge must be mastered by every individual Muslim in order to achieve maximum results related to the worship of reading the Holy Qur'an. Reading the Qur'an when referring to Allah's commands must be done with maximum tartil, namely knowing and obeying every sign. The reward promised by God based on the words of the Messenger of Allah is that whoever reads one letter to him will be rewarded with one goodness which will also be multiplied 10 times. The miracle of the Qur'an does not stop there. When pondered more deeply, the knowledge of Tajweed contains a deep philosophy, not only getting rewards from God, but a deep understanding of its
\end{abstract}


Agus Nur Qowim

philosophy will produce a thought about internalization, namely guidelines for character formation, or morals in accordance with the guidance of the Qur'an.

Keyword: Tajweed, Tartil, Internalization, Character of the Qur'ani

\section{Pendahuluan}

Al-Qur'an adalah segalanya bagi umat Islam, berfungsi sebagai way of life, yakni panduan hidup, atau rujukan bagaimana seorang muslim berperilaku, berbicara, dan sebagainya. Setiap permasalahan yang ada, semuanya akan dikembalikan dasar hukumnya kepada al-Qur'an. Tidak Terkecuali, pembangunan karakter demi terciptanya akhlak mulia dan budi pekerti luhur. Karena al-Qur'an sangat luar biasa, pantaslah jika mendapatkan predikat sebagai mukjizat tertinggi yang diterima oleh Rasulullah saw. Akhlak Rasul Muhammad s.a.w. juga merupakan refleksi dari kandungan al-Qur'an itu sendiri. Beliaulah manusia pilihan, yang diutus tiada lain kecuali untuk menyempurnakan akhlak ummatnya secara khusus dan manusia pada umumnya.

Isi kandungan al-Qur'an sangatlah menakjubkan. Ilmu-ilmu lain yang bertalian erat dengan al-Qur'an juga beraneka ragam. Salah satunya adalah ilmu yang membahas aturan bagaimana seseorang bisa membaca al-Qur'an dengan baik, benar, yang disebut dengan Ilmu Tajwid. Ilmu tajwid memberikan penjelasan bagaimana seorang pembaca al-Qur'an mengucapkan setiap huruf dengan tepat sesuai dengan makhrojnya. Seberapa panjang ukuran mad, kapan harus dengung, kapan membaca dengan jelas, bagaimana setiap huruf diucapkan sesuai dengan sifatnya, dan lainlain.

Bagi umumnya pembaca al-Qur'an, mereka menyisihkan waktu demi bercengkerama dengan firman Allah berdasarkan pada pengetahuan bahwa membaca al-Qur'an merupakan ibadah terbaik. Membaca al-Qur'an berbeda dengan membaca koran, karena Nabi bersabda dalam haditsnya bahwa satu huruf al-Qur'an yang dibaca akan memberikan kredit sebesar 10 poin. Allah telah memberikan sinyal di dalam al-Qur'an, bahwa siapapun hambanya yang mau merenung, mentadabburi al-Qur'an dengan pandangan hati yang jernih maka dia akan mendapatkan hakikat yang sebenarnya dari ilmu pengetahuan.

Apabila dikaji lebih dalam, ternyata Ilmu Tajwid memiliki keterkaitan erat dengan pembentukan karakter manusia melalui kegiatan membaca al-Qur'an. Jadi, siapapun yang rajin membaca al-Qur'an, dengan syarat membacanya sesuai dengan kaidah ilmu tajwid, secara tidak 
Internalisasi Karakter Qurani dengan Tartil Al-Qur'an langsung yang bersangkutan sedang membiasakan dirinya untuk berkarakter dan berakhlak sesuai dengan kandungan al-Qur'an.

\section{Membaca al-Qur'an dengan Tartil}

Perintah untuk membaca al-Quran dengan tartil termaktub secara gamblang pada dua ayat al-Qur'an berikut ini.

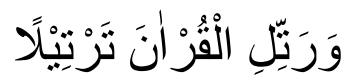

“Bacalah al-Qur'an dengan tartil semaksimal mungkin” (al-Muzzammil/73: 4)

Selain pada yat tersebut, perintah untuk membaca al-Qur'an dengan tartil juga terdapat pada firman Allah sebagai berikut:

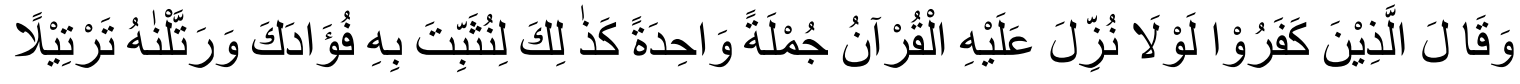

"Dan orang-orang kafir itu berkata: "Mengapa al-Qur'an itu tidak diturunkan kepadanya sekaligus? Demikianlah agar kami memperteguh hatimu (Muhammad) dengannya, dan kami membacakannya secara tartil (berangsur-angsur, perlahan, dan benar”) (al-Furqan/25: 32)

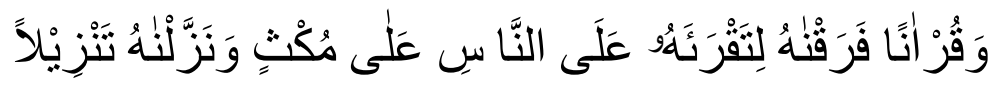

'Dan al-Qur'an itu (kami turunkan) berangsur-angsur agar engkau (Muhammad) membacakannya kepada manusia secara perlahan-lahan, dan kami menurunkannya secara bertahap" (al-Isra/17: 106)

K.H Muhsin Salim mendefinisikan tartil sebagai berikut: Pemahaman sebagian ulama memahami arti tartil dengan tajwid. Maksudnya adalah membaca al-Quran dengan perlahan-lahan, tenang, disertai dengan perenungan. Menebalkan huruf yang harus dibaca tebal, menipiskan huruf yang harus dibaca tipis, memanjangkan atau memendekkan sesuai dengan semestinya panjang dan pendek, mengeluarkan huruf dari tempat keluarnya sejalan dengan sifatnya, serta tidak mencampur aduk satu huruf dengan huruf yang lain. Pada ayat 4 surat Al-Muzzammil redaksi tartil diperkuat dengan diulangnya kata tartil. Hal tersebut menandakan bahwa membaca al-Qur'an dengan tartil adalah harga mati ${ }^{1}$.

\footnotetext{
${ }^{1}$ Muhsin Salim, Ilmu Tajwid Al-Qur'an, Belajar Membaca Al-Qur'an dengan Metode Tartil, Jilid I, (Jakarta: Kebayoran Widya Ripta, 2004), Cet. 2, h.xii)
}

IQ (Ilmu Al-qur'an): Jurnal Pendidikan Islam | Volume 2 No. 012019 | 19 
Agus Nur Qowim

Sedangkan K.H. Ahmad Fathoni mendefinisikan tartil sebagai berikut: Beliau menerjemahkan ayat 4 surat Al-Muzzammil: Bacalah al-Qur'an dengan tartil yang optimal. Maksudnya adalah bahwa perintah membaca al-Qur'an itu bukan sekedar dengan tartil, tetapi dengan tartil yang benar-benar berkualitas, sejalan dengan pendapat Ali bin Abi Thalib yakni membaguskan bacaan huruf-huruf al-Qur'an disertai dengan pemahaman tentang waqaf. AlQur'an merupakan bacaan yang mulia sehingga Allah sangat peduli dan tidak segan-segan memberikan perintah agar dalam membacanya tidak asal membaca, tetapi dengan tartil yang maksimal $^{2}$.

Membaca al-Quran dengan tartil yang maksimal bisa dipahami bahwa dalam membaca alQur'an itu harus bertajwid. Yakni membaca al-Qur'an sesuai dengan panduan ilmu tajwid. Supaya seseorang bisa mencapai taraf itu, maka harus memahami ilmu tajwid secara sempurna baik secara teoritis ataupun praktis. Hal tersebut bisa dicapai dengan berguru kepada para ahli.

Mengapa harus berguru kepada ahli? Karena untuk bisa mempraktikkan teori yang sudah dikuasai seorang murid harus memperhatikan secara langsung, bagaimana guru mengucapkan huruf demi hurf, bagaimana guru mencontohkan cara membaca izhar, idgham, ikhfa, iqlab dan berbagai jenis bacaan lainnya dengan tepat.

Tajwid secara etimologi berarti tahsin (memperbaiki). Secara istilah adalah: ilmu yang mempelajari bagaimana mengucapkan huruf-huruf arab (al-Quran) dengan benar, disertai dengan pengetahuan tentang makhroj dan sifat-sifat dari setiap huruf tersebut ${ }^{3}$. Hukum mempelajari (menguasai) ilmu tajwid adalah fardu kifayah, tetapi mengamalkan atau menerapkan ilmu tajwid ketika membaca al-Qur'an adalah fardhu 'ain bagi setiap muslim baik laki-laki maupun perempuan $^{4}$.

Al-Qur'an adalah kalamullah yang diturunkan kepada Nabi Muhammad saw. yang disampaikan (diriwayatkan) kepada kita dengan mutawattir, membacanya bernilai ibadah di hadapan Allah. Oleh karena itu, para ahli al-Qur'an dan umat islam yang hendak membacanya harus memperhatikan adab dan akhlak terhadap al-Qur'an.

Adab bagi para santri atau murid terkait dengan dirinya dan gurunya adalah:

\footnotetext{
${ }^{2}$ Ahmad Fathoni, Petunjuk Praktis Tahsin Tartil Al-Qur'an Metode Maisura, (Jakarta:Institut PTIQ Jakarta \& Pesantren Takhasus IIQ Jakarta, 2016), h.3.

${ }^{3}$ Rahab Muhammad Mufiid Syaqaqi, Hilyah al-Tilawah fi Tajwiidul Qur'an al-Kariim, (Jeddah, Maktabah Rowai'ul Mamlakah Al Mamlakah al-“arabiyyah al-su’udiyyah, 2011), h.51.

${ }^{4}$ Muhammad Ahmad Ma'bad, Al-Mulakhkhos al-Mufiid fii 'Ilmi at-Tajwid, (Mesir:Darussalam, 2009), h.8. 20 | IQ (Ilmu Al-qur'an): Jurnal Pendidikan Islam | Volume 2 No. 012019
} 
harus memasang niat ikhlas dalam rangka menggapai ridho Allah swt. Ibnu Mas'ud meriwayatkan bahwa: barangsiapa membaca al-Qur'an dalam rangka mengharapkan Ridho Allah ta'ala, maka dia akan mendapatkan pahala dalam setiap huruf berupa sepuluh kebaikan, atau dihapuskan baginya sepuluh keburukan, (H.R. al-Baihaqi)

Harus berusaha untuk selalu mengulang bacaannya. Belajar untuk istiqamah membaca ayat-ayat al-Qur'an baik di waktu siang maupun malam, ketika melaksanakan shalat atau di luar shalat

Tidak menukarkan, menjual al-Qur'an dengan kemuliaan, kedudukan yang bersifat duniawi. Semestinya seseorang yang dikaruniai kemampuan bisa membaca al-Qur'an dengan baik dia bersyukur kepada Allah, selalu memuji kebesaran Allah, menjadikan al-Qur'an sebagai sarana dzikir (mengingat) Allah, bertawakkal kepada Allah, sarana untuk memohon kepada Allah, dan lain sebagainya.

Hendaklah seorang murid menjaga sikap terhadap gurunya, supaya memperoleh kemanfaatan dari ilmu yang telah dipelajari dari guru.

Bagi seorang pembaca al-Qur'an, dia harus menjaga sikap, dan menjaganya ketika ia membaca. Selain apa yang telah diungkapkan pada paragraph sebelumnya, beberapa hal lain yang perlu diperhatikan ketika membaca al-Qur'an adalah sebagai berikut:

Membaca al-Qur'an dengan posisi duduk (bersila bagi laki-laki, bersimpuh bagi perempuan

1. Berada dalam kondisi suci (berwudlu)

2. Memakai pakaian yang bersih dan suci.

3. Tenang

4. Membaca dengan khusyu'

5. Tawadlu'

6. Berusaha menghadirkan keagungan Allah

7. Mentadabburi maknanya

Memperhatikan apa-apa yang terkandung dalam ayat dan hukum, merasa senang dan menampakkan wajah atau ekspresi berseri-seri ketika ayat yang dibaca berkaitan dengan kenikmatan dan surga. Sebaliknya, akan terasa takut dengan menampakkan ekspresi wajah murung apabila ayat yang dibaca berkaitan dengan ayat-ayat adab dan neraka. 
Selain itu seorang qari' harus membaca al-Qur'an dengan tartil bertajwid, menjaga hakhak yang ada sesuai dengan kemampuannya terkait dengan sifat dan makhroj setiap huruf , mad(panjang pendek), ghunnah, dan lain sebagainya dari hukum-hukum tajwid, dengan harapan supaya Allah swt menerima ibadahnya membaca al-Qur'an, memberikan kabar gembira dengan surga dan ridlo-Nya.

Metode bagaimana seseorang bisa membaca al-Qur'an dengan tartil yang indah juga perlu diperhatikan. Metode merupakan cara-cara yang diterapkan oleh guru terhadap muridnya sehingga tercapai tujuan pengajaran yang diinginkan ${ }^{5}$. Dengan metode yang tepat maka hasil tartil yang dicapai semakin efektif dan efisien.

\section{Internalisasi Karakter Qur'ani}

Secara etimologis internalisasi berasal dari kata internal: sesuatu yang berada di dalam, ditambah dengan akhiran isasi yang berate sebuah proses. Internalisasi adalah sebuah proses bagaimana sesuatu masuk, menyatu ke dalam (diri seseorang). dengan kata lain internalisasi sepadan dengan istilah pembiasaan. Pembiasaan terhadap sesuatu berdasarkan latihan dan percontohan. Hal tersebut termaktub di dalam al-Qur'an Surat al-Ahzab/33: 21 sebagai berikut:

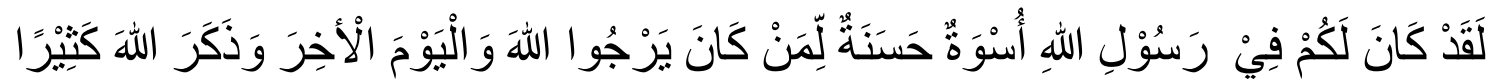

“Sesungguhnya telah ada pada diri Rasulullah itu suri tauladan yang baik bagimu (yaitu) bagi orang yang mengharap (rahmat) Allah dan (kedatangan) hari kiamat dan dia banyak menyebut Allah".

Karakter menurut Kamus Besar Bahasa Indonesia memiliki arti Sifat-sifat kejiwaan, akhlak atau budi pekerti yang membedakan seseorang dari yang lain ${ }^{6}$. Sedangkan qur'ani mengandung pengertian segala sesuatu yang berlandaskan atau berdasarkan al-Qur'an, sesuai dengan isi kandungan al-Qur'an, atau memiliki sifat sebagaimana apa yang termaktub dalam alQur'an. Jadi, karakter qur'ani adalah akhlak atau budi pekerti yang sesuai denagn tuntunan alQur'an.

Allah berfirman dalam al-Qur'an surat Al-Qalam/68: 4

\footnotetext{
${ }^{5}$ Darwyn Syah, dkk., Perencanaan Sistem Pengajaran Pendidikan Agama Islam, (Jakarta: Gaung Persada Press, 2007), Cet. 2, h.133.

${ }^{6}$ Pengertian Karakter, Pustaka.pandani.web.id/2013/03/pengertian-karakter.html/m=1. Diakses pada hari kamis, 20 Oktober 2016 pukul 09.45 di Bogor.

22 | IQ (Ilmu Al-qur'an): Jurnal Pendidikan Islam | Volume 2 No. 012019
} 
Internalisasi Karakter Qurani dengan Tartil Al-Qur'an

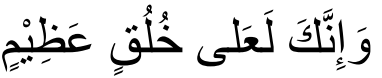

\section{"Dan sesungguhnya engkau benar-benar berbudi pekerti luhur"}

Ayat di atas menjelaskan bahwa Rasul adalah sosok yang memiliki budi pekerti luhur. Budi pekerti luhur itu lebih mahal dibandingan dengan sesuatu yang sifatnya harta dunia. Budi pekerti atau akhlak yang mulia akan menyatu dan selalu menghiasi tingkah laku seseorang jika yang bersangkutan sudah bersusah payah dan istiqomah untuk membiasakannya. Cerminan dari iman yang kuat, maka hati, ucapan dan perbuatannya akan selalu berlandaskan pada syariat Allah. Tidak munafik, yakni ketika apa yang dilakukan atau diucapkan tidak bersesuaian dengan hatinya. Hadist rasulullah juga mensinyalir bahwa beliau memerintahkan supaya umatnya mempunyai akhlak yang mulia.

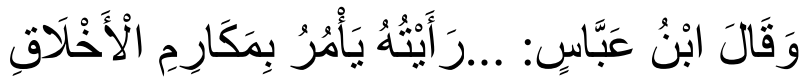

"Diriwayatkan oleh ibnu abbas: beliau menyaksikanbahwasanya Rasul saw memerintahkan agar umatnya mengerjakan akhlak-akhlak yang mulia. (H.R. Bukhori) ${ }^{7}$

Abdullah Bin Umar juga meriwayatkan sebuah hadits tentang akhlak mulia yang berbunyi:

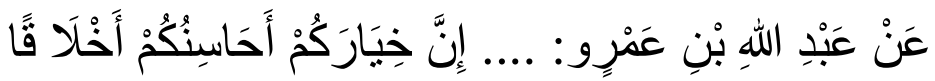

"Sesungguhnya yang terbaik diantara kalian adalah yang paling bagus akhlaknya” (H.R. Bukhori, nomor 6035) ${ }^{8}$

Banyak sekali akhlak-akhlak mulia yang diajarkan oleh al-Qur'an, seperti sabar, syukur, berparadigma positif, visioner, adil, tidak berburk sangka, tidak sombong, saling mencintai dan menyayangi, peduli terhadap sesame, dan sebagainya.

Al-Ghazali mendefinisikan akhlak sebagai suatu sifat yang tertanam dalam jiwa yang daripadanya timbul perbuatan-perbuatan dengan mudah, dengan tidak memerlukan pertimbangan pikiran terlebih dahulu. Sedangkan Prof Ahmad Amin mendefinisikan akhlak sebagai kehendak yang dibiasakan. Kehendak merupakan ketentuan dari berbagai keinginan manusia setelah bimbang, sedangkan kebiasaan adalah perbuatan yang diulang-ulang sehingga mudah untuk dikerjakan. Baik kehendak atau kebiasaan mempunyai nilai postitif, apabila kedua kekuatan positif itu digabungkan maka akan memunculkan kekuatan lebih besar yang disebut dengan akhlak.

7 Abi Abdillah Muhammad Ismail bin Ibrahim Al-Bukhori, Sohih Bukhori, dalam bab husnil khuluqi was sakhooi wama yukrohu minal bukhli, (tt: Dar Ibnu Haitsam, 2004), h. 712.

${ }^{8}$ Abi Abdillah Muhammad Ismail bin Ibrahim Al-Bukhori, Sohih Bukhori, dalam bab husnil khuluqi was sakhooi wama yukrohu minal bukhli, hadits nomor 6035, h. 713. 
Pada dasarnya suara hati manusia memiliki dua sisi, akan mengikuti kebaikan atau keburukan. Mengikuti tuntunan Allah, atau mengikuti langkah-langkah syaiton. Qolbu manusia akan merangsang pikiran untuk menggerakkan raga ke rah kebaikan. Akan tetapi, di sisi lain, nafsunya akan menjadi penyeimbang, menariknya untuk condong kepada kejelekan.

Oleh karena itu, agar akhlak mulia alias budi pekerti luhur menjadi relfleksi dalam setiap langkah kehidupan, manusia harus mengendalikan dirinya, membiasakan dengan mencoba dan terus mencoba supaya dirinya diliputi dengan kebaikan.

Memang pada awalnya perbuatan baik itu berat untuk dilaksanakan. Maka harus diawali dengan paksaan. Apabila seseorang sudah merasakan nikmat dan nyaman terhadap akhlak-akhlak mulia yang selalu mengiringi kehidupan, maka secara otomatis rasa terpaksa akan hilang. Proses pembiasaan akhlak-akhlak qur'ani tersebut menurut penulis cocok apabila dikaitkan dengan 3 langkah yang dibahas dalam ranah tasawuf, yakni takholli, tahalli, tajalli. ${ }^{9}$

Agar budi pekerti dan akhlak qur'ani melekat pada diri seseorang tahap pertama yang harus dilakukan adalah takholli. Yakni mengosongkan diri. Membuang sedikit demi sedikit tabiat setan, watak durjana dan angkara murka pada diri kita masing-masing. Bagi yang sudah terbiasa melakukan hal-hal yang tidak sesuai dengan tuntunan al-Qur'an, sangatlah berat untuk menghentikannya karena sudah merasa nyaman, atau malah malu untuk melakukan hal-hal yang baik. Seperti seseorang malu untuk berkata jujur. Dia lebih nyaman berbohong. Di sisi lain, ada yang mengedepankan amanah, diabndingkan dengan mengutamakan kesabaran.

Hal itu butuh perjuangan, kikislah sedikit demi sedikit perilaku yang tidak terpuji tersebut. Perlahan kita hiasi kehidupan kita dengan sabar, syukur, qanaah, dan sebagainya. Lambat laun kita akan terbiasa dengan hal tersebut sehingga, jika hal itu benar-benar sudah menjadi landasan hidup maka sirnalah sifat-sifat negative dalam diri. Kita enggan untuk berbohong, malu berbuat zalim, dan sebagainya.

Hal pertama ini cukuplah berat, apalagi bagi seseorang yang sudah terbiasa berperilaku jahiliyah. Pasti dia akan merasa malu ketika mengawali berbuat kebaikan. Khalayak akan menggunjingnya, karena dia terbiasa melakukan perbuatan-perbuatan yang dilarang Allah. Sejatinya, yang demikian tersebut bukanlah dia malu kepada siapapun, tetapi dia malu terhadap dirinya sendiri.

${ }^{9}$ Ali Jum'ah (Terjemahan M. Farid Wajdi), Meniti Jalan Tuhan, (Jogjakarta: Pustaka Ilmu, 2013), h. 24-28. 24 | IQ (Ilmu Al-qur'an): Jurnal Pendidikan Islam | Volume 2 No. 012019 
Jika langkah pertama itu sudah terpatri, maka bersihlah hati seseorang. Diibaratkan seperti rumah yang kosong, tugas berikutnya adalah mengisinya dengan perabotan yang indah. Diisi dengan lemari yang bagus, kursi yang menawan, dan hiasan-hiasan dinding yang menambah segar suasana.

Andaikata hati itu laksana piring yang baru saja di cuci bersih, maka hidangkanlah di atasnya makanan-makanan yang lezat dan memikat hati. Isi tersebut akan sangat mempengaruhi tempat yang diisi, apabila suatu tempat diisi dengan suatu yang indah dan mengesankan, maka tentu menjadi luar biasa. Sebaliknya bila diisi dengan sesuatu yang jelek maka wadah yang bagus itu tidak ada fungsinya. Bayangkan, piring yang barusaja dicuci bersih sehingga mengkilap dan wangi, tiba-tiba diisi dengan sampah makan. Sangat disayangkan. Inilah yang disebut dengan tahalli. Yaitu mengisi hati yang sudah bersih dengan hal-hal, perbuatan, dan sifat yang disukai Allah swt dan Rasulnya. Dengan demikian kebersihan hati akan tetap terjaga bahkan semakin terang sinarnya.

Jika kedua tahap sudah dilampaui maka tentunya sifat-sifat dan karakter qur'ani itu akan menyatu dan bertajalli. Menjelma ke dalam diri setiap manusia secara otomatis segala perbuatannya akan selalu memancarkan kedamaian, keindahan, dan kenikmatan bagi yang memandangnya, karena setiap perbuatan ucapan dan tingkah lakunya merupakan cerminan akhlak al-Qur'an. Inilah yang disebut dengan tajalli.

\section{Kaitan Membaca Al-Quran dengan Tartil dan Melekatnya Karakter Qur'ani}

Membaca al-Qur'an dengan tartil yang maksimal merupakan keharusan. Mengetahui tentang falsafah qur'aniyah juga harus diusahakan. Ada sindiran tajam yang ditujukan kepada ummat yang kepadanya diturunkan Al-Qur'an. Allah berfirman:

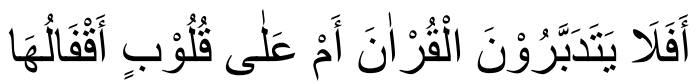

"Maka apakah mereka tidak memperhatikan al-Qur'an, ataukah hati mereka terkunci?" (Q.S. Muhammad/47: 24)

Dari ayat tersebut bisa dipahami bahwa, usaha untuk bisa membaca al-Qur'an dengan tartil yang prima bukanlah akhir. Setelah pandai membaca, maka semestinya, kita sebagai pembaca alQur'an sedikit-demi sedikit harus mulai memperhatikan Falsafah apa yang terdapat di dalam ayatayat yang sudah dibaca. Dengan demikian, isi, dan kandungan tentang arah dan petunjuk kehidupan bisa kita implementasikan dalam setiap sendi kehidupan. 
Logis, jika ayat yang pertama diturunkan adalah terkait dengan perintah membaca. Allah berfirman:

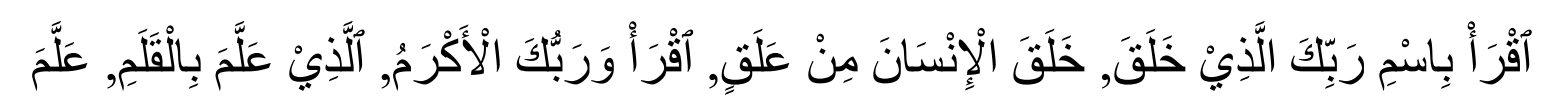

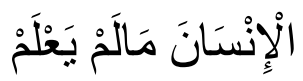

"Bacalah dengan nama Tuhanmu yang maha pencipta. (Dia) menciptakan manusia dari segumpal darah. Bacalah! Dan Tuhan mu itu adalah Maha Mulia.(Dia) yang mengajarkan dengan Qalam. Mengajari manusia apa-apa yang tidak diketahuinya. (Q.S. Al-`Alaq/96: 1-5)

Menurut Buya Hamka ${ }^{10}$, membaca adalah awal terbukanya perkembangan dalam segala hal, termasuk agama. Maka, orang yang beriman merefleksikan diri pada Rasulullah, dia harus mau membaca Wahyu Allah dengan kejernihan hati dan pikiran. Membaca tidak dalam artian membaca secara harfiah. Membaca keadaan. Membaca dan mempersiapkan apa yang harus dipersiapkan dalam rangka menghadapi masa depan, dan lain-lain. Memperhatikan, dan membaca inti kandungan ayat-ayat Allah juga menjadi cirri-ciri bagi orang yang berpikir.

Fenomena yang kita saksikan pada kehidupan masyarakat modern adalah pudarnya buadaya mencintai kegiatan "nderes” al-Qur'an. Berbeda dengan adat kebiasaan masyarakat islam Indonesia dahulu, selepas maghrib hamper setiap rumah terdengar suara seperti suara lebah, yang apabila didekati itu adalah suara orang membaca al-Qur'an. Suara tersebut tentu sangat terdengar jelas di setiap Langgar, Musholla, dan Masjid-masjid di manapun berada.

Berbeda dengan era modern. Suara-suara yang bergema adalah suara TV, dimana sebagian besar keluarga yang ada di dalamnya sedang asyik melihat para artis berjoget. Masjid, musholla dan langgar sepi. Karena, adat dan kebiasaan sebagian besar masyarakat telah berubah. Mereka sudah meninggalkan kebiasaan dimana kebiasaan itu merupakan salah satu indikator manusia terbaik di sisi Allah, yakni membaca al-Qur'an.

Kualitas bacaan antara santri dahulu dan sekarang juga jauh berbeda. Dahulu, untuk membaca surat Al-Fatihah saja, bisa satu tahun belum khatam, sehingga untuk khatam 30 juz alQur'an membutuhkan waktu yang sangat lama. Otomatis hasilnya matang dari segi bacaan. Meskipun mungkin tidak bisa melagukan dengan bagus, tetapi bacaan benar dan fasih. Santri zaman sekarang tidak betah untuk berlama-lama mengaji, maka hasilnya pun masih premature.

${ }^{10}$ Hamka, Tafsir Al-Azhar Juz XXX, (Jakarta: Pustaka Panjimas, 1998). h. 215. 26 | IQ (Ilmu Al-qur'an): Jurnal Pendidikan Islam | Volume 2 No. 012019 
Sok berlagu, padahal panjang pendek sja masih belepotan. Ingatlah, bahwa salah satu syarat bisa memperoleh ilmu adalah membutuhkan waktu yang lama, sebagaimana dituturkan pada kitab Ta'limul muta'allim sebagi berikut: Tidak akan mampu seseorang meraih ilmu kecuali dia memenuhi enam criteria, salah satunya adalah thuuli zamaani. Belajar itu membutuhkan waktu yang lama, bahkan konsep belajar itu adalah sepanjang hayat ${ }^{11}$.

Masyarakat modern adalah masyarakat yang pola pikirnya realistis. Salah satu usaha yang harus dilakukan adalah melogiskan kepada mereka bahwa membaca al-Qur'an adalah amal mulia dan utama. Maka, penulis mempunyai pengalaman sebagai hasil membaca dan mentadabburi alQur'an. Bagaimana mengkaji falsafah dari ilmu tajwid. Bahwasanya bukan sembarangan, AlQur'an sebagai Wahyu ilahiyah diturunkan kepada Rasulullah saw. Merupakan tuntunan kehidupan. Bahwasanya dengan mengkaitkan falsafah ilmu tajwid, bisa menjadi sarana membangun karakter, dan semangat berinteraksi dengan al-Qur'an.

Beberapa keterkaitan, bahwa dengan membaca al-Qur'an yang baik dan benar (tartil) yang diikuti tadabbur, yakni berpikir tentang makna apa yang terkandung di dalamnya, terutama kaitan mengapa Allah memerintahkan kita untuk membaca dengan tartil maksimal bisa penulis jabarkan dengan gambaran sebegai berikut:

Kita tentu sangat mengenal bacaan izhar, yakni jelas, dan tegas ketika membaca ayat-ayat dimana ada nun sukun atau tanwin bertemu dengan huruf halaq yang berjumlah enam. Tidak ada dengung. Apakah cukup sampai di situ, Selesai dengan membaca Izhar ayat-ayat yang di dalamnya terdapat bacaan izhar?. Coba sejenak kita merenung, mengapa harus ada bacaan izhar? Tentu bagi yang mau merenung, pasti ada makna tersirat. Ahli al-Qur'an harus mengambil dan menerapkan falsafah izhar dalam kehidupannya. Dia harus jelas, tegas dalam setiap langkahnya. Tidak mencampur aduk antara yang hak dan bathil. Dia berani mengatakan kebenaran walaupun pahit. Itulah karakter yang Allah inginkan dari bacaan izhar. Menjadi orang yang benar, shiddiq. Dengan kelurusan dan ketegsannya maka, karakternya itu akan menggiring kepada kebaikan yang akan bermuara pada surga.

Ada beberapa hukum bacaan yang akan bisa terdefinisi, tergantung kepada huruf yang dihadapinya. Seperti hukum nun sukun dan tanwin misalnya, tidak akan terdefinisi menjadi bacaan apa, sebelum jelas huruf apa yang di hadapinya. Jika di hadapan nun sukun atau tanwin ada huruf

\footnotetext{
${ }^{11}$ Aliy As'ad, Terjemah Ta 'limul Muta'allim, Bimbingan Bagi Penuntut Ilmu Pengetahuan (Kudus: Menara Kudus, 2007), h. 32.
} 
ya, maka baru bisa dikatakan terjadi bacaan idgham bighunnah. Hal tersebut menggambarkan bahwa manusia itu harus selalu memandang masa depan. Dia harus mempersiapkan dirinya untuk menghadapi masa depan. Dengan demikian, orang yang rajin membaca al-Qur'an diajarkan menjadi manusia yang visioner, progresif, dan selalu memandang masa depan. Dia mempunyai motto bahwa hari ini harus lebih baik dari kemarin. Dan hari esok harus lebih baik dari sekarang. Dengan demikian, dia akan termasuk golongan orang yang beruntung, yakni jika hari yang dilaluinya selalu lebih baik dari hari yang sudah dilaluinya.

Ada juga hukum bacaan yang tergantung kepada harokat huruf sebelumnya. Bacaan terkait tafkhim dan tarqiq (tebal dan tipis) baik untuk lafazh Allah, atau hukum ro, tergantung dari harokat huruf sebelumnya. Hal tersebut memberikan ibrah bagi pecinta al-Qur'an supaya tidak mengabaikan masa lalu. Masa lalu terkait dengan pengalaman. Sedangkan pengalaman adalah guru yang paling berharga. Selain menjadi pribadi yang progresif, ahlul qur'an juga diajarkan unutk melihat masa lalu. Masa lalu merupakan guru yang berharga. Apabila masa lalu penuh dengan keberhasilan, maka tugas berikutnya adalah mempertahankan dan memperbaiki. Apabila masa lalu penuh dengan kegagalan, maka ingatlah bahwa kegagalan adalah keberhasilan yang tertunda dan guru yang paling berharga.

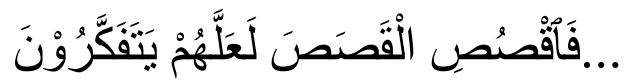

"Ceritakanlah kisah-kisah itu (kepada mereka) supaya mereka berpikir"(Q.S. Al-A'raf/7: 176)

\section{Kesimpulan}

Dari pemaparan yang telah disampaikan dapat disimpulkan beberapa hal berikut ini:

1. Membaca Al-Quran harus didukung dengan penguasaan ilmu tajwid yang memadai.

2. Dianjurkan supaya membaca al-Qur'an dengan tartil semaksimal mungkin.

3. Perenungan dan internalisasi terhadap falsafah ilmu tajwid, akan menghantar seseorang kepada terbentuknya karakter dan kepribadian sesuai denagn tuntunan al-Qur'an

\section{Daftar Pustaka}

28 | IQ (Ilmu Al-qur'an): Jurnal Pendidikan Islam | Volume 2 No. 012019 
Al-Bukhori, Abi Abdillah Muhammad Ismail bin Ibrahim, Sohih Bukhori, dalam bab husnil khuluqi was sakhooi wama yukrohu minal bukhli, tt: Dar Ibnu Haitsam, 2004.

As'ad, Aliy, Terjemah Ta'limul Muta 'allim, Bimbingan Bagi Penuntut Ilmu Pengetahuan, Kudus: Menara Kudus, 2007.

Fathoni, Ahmad, Petunjuk Praktis Tahsin Tartil Al-Qur'an Metode Maisura, Jakarta:Institut PTIQ Jakarta \& Pesantren Takhasus IIQ Jakarta, 2016.

Hamka, Tafsir Al-Azhar Juz XXX, Jakarta: Pustaka Panjimas,1998.

Jum'ah, Ali (Terjemahan M. Farid Wajdi), Meniti Jalan Tuhan, Jogjakarta: Pustaka Ilmu, 2013.

Ma'bad, Muhammad Ahmad, Al-Mulakhkhos al-Mufiid fii 'Ilmi at-Tajwid, Mesir:Darussalam, 2009.

Pengertian Karakter, Pustaka.pandani.web.id/2013/03/pengertian-karakter.html/m=1. Diakses pada hari kamis, 20 Oktober 2016 pukul 09.45 di Bogor.

Salim, Muhsin, Ilmu Tajwid Al-Qur'an, Belajar Membaca Al-Qur'an dengan Metode Tartil, Jilid I, Jakarta: Kebayoran Widya Ripta, 2004.

Syah, Darwyn, dkk., Perencanaan Sistem Pengajaran Pendidikan Agama Islam, Jakarta: Gaung Persada Press, 2007.

Syaqaqi, Rahab Muhammad Mufiid, Hilyah al-Tilawah fi Tajwiidul Qur'an al-Kariim, Jeddah, Maktabah Rowai’ul Mamlakah Al Mamlakah al-“arabiyyah al-su’udiyyah, 2011. 